\title{
DESPRE EVLAVIA EUHARISTICĂ ÎN VIZIUNEA SFÂNTULUI IOAN GURĂ DE AUR
}

Stelian Gomboş*

\begin{abstract}
This study wants to point out and to underline once again the importance of Holy Communion in the faithful life; without which they cannot purify themselves, nor redempt from a spiritual point of view.

The material presented also emphasizes the sacred value of this unbloody sacrifice, which is Holy Communion, a sacrifice brought by Our Lord Jesus Christ, who brings Himself for us and for our redemption, thus reminding us of His Sacrifice on Golgotha, but in a spiritual way, in and through the Church which we make up and must obey and which is actually led by Jesus Christ - Its
\end{abstract} founder.

This material reveals the unbreakable and reciprocal relationship between Holy Eucharist and Church, between Holy Communion and the other Holy Mysteries of the church, as a source of the holy blessing of the saints over people. It emphasizes the role of Holy Eucharist which makes possible both the communion between God - Jesus Christ, the human- and people but also the communion between people who are the members of the church and who make up its Body, as Jesus Christ is its Head.

This study is based on different quotations from The Holy Bible , whose role is to emphasize those mentioned in it, and which are part of the spiritual treasure of the Church, as well as the Church is blessed by Jesus Christ through its servants- the priests. This precious treasure, from a spiritual point of view, which is Holy Eucharist- the one that through the Holy Liturgy changes into the Holy Bread-Body and the Holy Blood which gives life, provides us all eternal life in the Kingdom of Heavens.

Keywords: Holy Eucharist, Sacrifice, Holy Mysteries, Holy Communion, Jesus Christ, Holy Bible, Holy Liturgy.

${ }^{*} \mathrm{PhD}$, Superior Counsellor of State Secretary for Cults. 


\section{Introducere - Pregătirea pentru primirea Sfintelor Taine}

Trebuie subliniat de la început faptul că „de la Sfântul Ioan Gură de Aur nu ne-a rămas o scriere mică şi metodică despre dumnezeiasca Euharistie, ci fragmente de o rară frumusețe şi de o adâncă simţire creştină în mai toate scrierile sale" . Înainte de a vorbi despre păcatele care ne împiedică de la o participare activă şi conştientă la Sfânta Liturghie, trebuie să ştim de ce anume avem nevoie de o astfel de pregătire (valabilă atât pentru mireni cât şi pentru clerici). De ce trebuie să fim atât de atenți cu noi înşine? Înaintea cui trebuie să ne înfătiş̧ăm? Cu cine ne vom împărtăşi?

La toate aceste întrebări, Sfântul Ioan Gură de Aur ne dă un răspuns pe măsură. El ne atrage atenția asupra faptului că participarea noastră la Sfânta Liturghie nu se poate face oricum, ci doar pregătiți trupeşte şi sufleteşte (duhovniceşte), fiindcă noi Îl vom vedea şi chiar ne vom hrăni cu Domnul şi Mântuitorul nostru Iisus Hristos. Cel care pe drept cuvânt a fost numit „Doctor Eucharistiae” a încercat din răsputeri să ne conştientizeze asupra faptului că Trupul şi Sângele pe Care noi îl primim în cadrul Sfintei Liturghii sunt chiar cele ale Domnului Iisus Hristos istoric, deci nu sunt simboluri ori închipuiri, ci prin intermediul şi cu ajutorul elementelor fizice palpabile şi văzute, pâinea şi vinul (dar care se sfințesc la Epicleză) ne împărtăşim cu (adică mâncăm) Însuşi Trupul şi Sângele Fiului lui Dumnezeu ${ }^{2}$, Persoana a doua a Sfintei Treimi, Care „S-a pogorât din ceruri... şi din fecioara Maria S-a făcut om”3; „Corpul Domnului din Cina cea de Taină... întru nimic nu se deosebeşte de Corpul Lui. Se înțelege că noi, care ne împărtăşim din Corpul şi din Sângele Lui, ne

${ }^{1}$ Dr. Marius Telea, Sfânta Euharistie în gândirea Sfântului Ioan Gură de Aur, în „Revista Teologică”, anul IV (1994), nr. 1, p. 32.

${ }^{2}$ Pr. Prof. Univ. Dr. Ioan G. Coman, Sensul Ecumenic al Sfintei Euharistii la Sfântul Ioan Gură de Aur, în „Ortodoxia”, anul XVII (1965), nr. 4, p. 521; precum şi Pr. Prof. Univ. Dr. Dumitru Stăniloae, Taina Euharistiei - izvor de viață spirituală în Ortodoxie, în „Ortodoxia”, anul XXXI (1979), nr. 3 - 4, p. $343-344$.

${ }^{3}$ Articolul 3 din Simbolul de Credință. 
împărtăşim din Corpul Aceluia ce este în ceruri şi închinat de îngeri"'4.

Ceea ce a surprins întotdeauna pe cei care s-au aplecat asupra scrierilor Sfântului Ioan Hrisostom a fost realismul cu care acesta vorbeşte despre prezența reală a Lui Iisus Hristos în Sfânta Euharistie. Lecturând aceste pasaje, nu mai rămâne nici o urmă de îndoială că în cadrul Sfintei Liturghii, Iisus Hristos este jertfa şi jertfitorul („Cel ce se împarte...”), că există o singură jertfă şi un singur Jertfitor (aceeaşi şi Acelaşi de la Cina cea de Taină) ${ }^{5}$. „Astăzi tot El este cel care lucrează şi Care Se predă, ca şi atunci”. „Masa aceasta este aceea de la Cina cea de Taină, întru nimic mai prejos. Na făcut-o pe aceea Hristos, iar pe aceasta un om. $\mathrm{Nu}$, ci şi pe aceasta tot El. Acesta este foişorul acela unde era El cu ucenicii lui atunci"” „Domnul, Care le-a săvârşit atunci la cina aceea, acelaşi le săvârşeşte şi le preface" "Credeți, dar, că şi acum este Cina cea de taină la care Domnul a mâncat. Întru nimic nu se deosebeşte aceea de aceasta. Pe

${ }^{4}$ Sfântul Ioan Gură de Aur, Omilia III, în Comentariile sau explicarea Epistolei către Efeseni a celui intru sfinți părintelui nostru Ioan Chrisostom, Arhiepiscopul Constantinopolei, traducere din limba greacă, ediția de Oxonia, 1852, de Arhim. Theodosie Athanasiu - Egumenul Bisericii Sfântul Spiridon, Tipografia Editoare „Dacia” P. Iliescu \& D. Grossu, Iaşi, 1902, p. 29.

${ }^{5}$ Idem, Omilia XVII, în Comentariile sau explicarea Epistolei către Evrei a celui întru sfinți părintelui nostru Ioan Chrisostom, Arhiepiscopul Constantinopolei, traducere din limba greacă, ediția de Oxonia, 1862, de Theodosie Romanul, Episcopul Romanului, Tipografia Cărților Bisericeşti, Bucureşti, 1923, p. 230.

${ }^{6}$ Idem, Omilia XXVII, în Comentariile sau explicarea Epistolei I către Corintenii a celui întru sfinți părintelui nostru Ioan Chrisostom, Arhiepiscopul Constantinopolei, traducere din limba greacă, ediția de Oxonia, 1847, de Arhim. Theodosie Atanasiu - Egumenul Mănăstirii Precista Mare din Roman, Atelierele grafice Soce \& Co, Bucureşti, 1908, p. 371.

${ }^{7}$ Idem, Comentar la Evanghelia de la Ioan, Omilia 46, traducere din limba franceză de Diac. Gheorghe Băbuț, Editura „Pelerinul Român”, Oradea, 1997, p. 223.

${ }^{8}$ Idem, Omilia LXXXII, în Scrieri partea atreia, Omilii la Matei, traducere, introducere şi note de Pr. Dr. Dumitru Fecioru, Colecţia Părinţi şi Scriitori Bisericeşti (PSB), vol 23, E.I.B.M.B.O.R., Bucureşti, 1994, p. 935. 
aceasta n-o săvârşeşte un om, iar pe cealaltă Hristos, ci El o săvârşeşte şi pe aceasta şi pe aceea. Când îl vezi pe preot că-ţi dă trupul şi sângele Lui, nu socoti că preotul face aceasta, ci că mâna lui Hristos se întinde spre tine"".

Dacă noi ne dăm seama de realitatea acestor lucruri, atunci nu mai putem sau nu ar trebui să ne mai apropiem oricum şi oricând de Sfintele lui Hristos Taine, ci mai înainte de a face aceasta trebuie să urmărim să ne curăţim atât trupeşte cât şi sufleteşte. Sfântul Ioan Gură de Aur cere tuturor acelora care doresc să se împărtăşească un singur lucru: o conştiinţă curată. Pentru ca noi să dobândim o astfel de conştiinţă, trebuie ,să ne eliberăm de obiceiurile cele lumeşti şi păgâneşti, să ne depărtăm mult de ele, ca să vedem pe Hristos"10 . Obiceiurile păgâneşti de care vorbeşte Sfântul Ioan Gură de Aur sunt păcatele, atât sufleteşti cât şi trupeşti. Amândouă ne țin departe de Iisus Hristos, dar pot fi abandonate prin conlucrarea şi colaborarea dintre voința noastră şi harul dumnezeiesc (care ajută doar pe cel care îşi doreşte cu adevărat să părăsească păcatul $)^{11} \cdot \mathrm{Cu}$ toţii ştim şi recunoaştem că eşantionul păcatelor este foarte larg şi foarte variat, însă având în vedere participarea noastră la Sfânta Euharistie, Sfântul Ioan Hrisostom condamnă în primul rând acele păcate care 1-au făcut atât pe Iuda, cât şi pe cei ce-i urmează acestuia, să se lepede de Iisus Hristos. În acest fel, orice creştin trebuie să se ferească în primul rând de iubirea de argint - arghirofilia (care se opune virtuții milosteniei). Dar nu doar această patimă ne pătează conştiința, ci în general tot păcatul, bine ştiind că ,păcatele sunt pricina tuturor relelor" ${ }^{\prime 2}$. Astfel că şi prefăcătoria, răutatea, înşelarea aproapelui, fățărnicia, răpirea (furtul şi hoția), hulirea învrăjbirea, zgârcenia,

\footnotetext{
${ }^{9}$ Idem, Omilia L, p. 582.

${ }^{10}$ Idem, Omilia IV, p. 96.

${ }^{11}$ Idem, Omilia LXXXII, p. 933. „Strădania omului nu este îndestulătoare, dacă omul nu se bucură de ajutorul cel de sus; şi iarăşi: nu se câştigă nimic de pe urma ajutorului de sus dacă nu ne dăm şi noi silinţa. Din acestea două se împleteşte virtutea: din ajutorul cel de sus şi din strădania”

12 Idem, Omilii despre pocăință, Omilia VII, traducere, introducere şi note de Pr. Dr. Dumitru Fecioru, E.I.B.M.B.O.R., Buureşti, 1998, p. 142.
} 
desfrânarea ${ }^{13}$ sunt piedici şi obstacole în urcuşul nostru duhovnicesc, cu alte cuvinte, păcate care nu îl recomandă pe creştin în faţa Domnului nostru Iisus Hristos.

Creştinul, conform spuselor Sfântului Ioan Gură de Aur, este omul înălțimilor ${ }^{14}$, de aceea, ,cel ce păcătuiește, acela este un om pur şi simplu, pe când cei ce fac fapte virtuoase aceia sunt oameni spirituali”" ${ }^{\prime \prime}$. Pentru a ajunge la înălţimile duhovniceşti, creştinul este dator să lucreze pământul virtuții. În lupta omului cu păcatul, virtutea care îl însoțeşte pe om pe tot parcursul urcuşului său către Dumnezeu este pocăința. Pocăința este virtutea căreia Sfântul Ioan i-a acordat o atenţie deosebită şi o preocupare specială, aşa încât a fost pe drept cuvânt numit dascăl al pocăinței. De ce este atât de mult prețuită de Sfântul Ioan aceasta? Răspunsul ni-l dă chiar el însuşi:

„-- Pentru ce te înfricoşezi, diavole, când este lăudată pocăința? Pentru ce te jeleşti, pentru ce te cutremuri?

- Da, pe dreptate mă jelesc şi mă tângui, răspunde diavolul, pentru că mari trofee mi-a răpit mie pocăința asta!

- Care trofee?

- Pe desfrânată, pe vameş, pe tâlhar, pe hulitorul şi marele prigonitor Pavel!" 16 .

Prin urmare, mare este virtutea pocăinței! Cel ce o îmbrăţişează pe aceasta poate scăpa foarte uşor de cursele vrăşmaşului şi capcanele diavolului, chiar de ar fi cel mai mare păcătos. Drept dovadă ne stau exemplele enumerate mai sus. Însă pocăința nu este doar o sforțare de moment, ci ea implică (ca toate celelalte virtuți) un efor permanent şi continuu din partea omului,

${ }^{13}$ Idem, Omilia I la vânzarea lui Iuda, 6, în Predici la Sărbători Împărăteşti şi Cuvântări de laudă la sfinți, E:I.B.M.B.O.R., Bucureşti, 2002, p. 56.

${ }^{14}$ Pr. Gheorghe Tilea, Evlavia Euharistică după Sfântul Ioan Gură de Aur, în „Studii Teologice”, nr. 9 - 10/1957, p. 635.

${ }^{15}$ Sfântul Ioan Gură de Aur, Omilia IX, 1, Omilii la Facere, vol. I, traducere, introducere şi note de Pr. Dr. Dumitru Fecioru, E.I.B.M.B.O.R., Bucureşti, 2003, p. 90.

${ }^{16}$ Idem, Omilii despre pocăință, Omilia II, traducere, introducere şi note de Pr. Dr. Dumitru Fecioru, E.I.B.M.B.O.R., Bucureşti, 1998, p. 27. 
efort susținut totdeauna de Dumnezeu, prin harul Său cel sfânt şi sfințitor. Dumnezeu, ne spune Sfântul Ioan Hrisostom, i-a dat omului multe feluri de pocăință, astfel că nimeni nu poate spune că este o virtute imposibil de îndeplinit. Dacă Dumnezeu ne-ar fi dat o singură modalitate şi cale de pocăință, n-am fi primit-o, ci am fi spus: „Nu putem să mergem pe această cale, nu putem să ne mântuim”. Dar aşa, Dumnezeu ți-a tăiat cuvântul acesta, că nu ți-a dat numai o cale de pocăință, nici două, nici trei, ci multe şi felurite, ca, prin mulțimea lor, să-ți facă lesnicioasă suirea la cer"17. Dintre „multele şi feluritele" căi de pocăință oferite nouă de Dumnezeu, Sfântul Ioan Gură de Aur ne pune înaintea conştiinței noastre cinci feluri sau modalități de a ne întoarce dinspre păcat spre Dumnezeu: recunoaşterea păcatului în faţa lui Dumnezeu (ori de câte ori păcătuim $)^{18}$, plângerea păcatelor săvârşite (care spală prin lacrimi de căință sinceră) ${ }^{19}$, smerenia ${ }^{20}$, milostenia $^{21}$ (numită şi ,marea şi

${ }^{17}$ Idem, Omilii despre pocăință, Omilia III, traducere, introducere şi note de Pr. Dr. Dumitru Fecioru, E.I.B.M.B.O.R., Bucureşti, 1998, p. 45.

18 „Ai păcătuit? Intră în Biserică şi spune-I lui Dumnezeu: Doamne, am păcătuit! Dumnezeiasca Scriptură zice: „Spune tu păcatele tale întâi, ca să te îndreptezi”. Spune păcatul, ca să scapi de păcat!” Idem, Omilia II, p. 28. Sfântul Ioan Gură de Aur obişnuieşte să dea două exemple: unul pozitiv şi altul negativ. În cazul de faţă ni-l arată pe Cain care nu s-a pocăit şi a murit în păcatul lui, dar şi pe David, care, datorită faptului că a mărturisit păcatul săvârşit, a dobândit iertare de la Dumnezeu (p. 29 - 33)

19 „Ai şi o altă cale de pocăință! Care-i aceia? Să-ți plângi păcatul! Ai păcătuit? Plângi, și astfel ți-ai șters păcatul! (Ex. Ahab cu Ilie, Iona, p. 34 - 38); Idem, Omilia II, p. 34. „Plânge-ți, dar, şi tu păcatul tău! Nu de mântuială, nici de formă, ci plângi cu amar ca Petru! Idem, Omilia III, p. 59.

${ }^{20}$ „Ai şi o a treia cale de pocăinţă! Care este aceasta, a treia cale de pocință? Smerenia. Smerește-te şi ți-ai şters mulțime de păcate”. Idem, Omilia II, p. 39. (Ex. Pilda Vameşului şi Fariseului, p. 39 - 42)

21 „Vă pun în față a patra cale de pocăință. Care-i aceasta? Milostenia, împărăteasa virtuților, aceea care duce iute pe oameni în bolţile cerului, apărătoarea noastră prea bună” (Ex. Sutaşul Corneliu. Cuvintele ,înaintea lui Dumnezeu” înseamnă: „De-ai avea multe păcate, nu te teme, că ai milostenia apărătoare!”. Nici una dintre puterile cele de sus nu-i va sta împotrivă. Milostenia îşi cere datoria, stând cu polița în mână. Însuşi Stăpânul ne-o spune: 
principala pocăință, în stare să rupă lanțul păcatului” şi fără de care „,pocăința este moartă şi lipsită de aripi”)"22 şi rugăciunea ${ }^{23}$ (care poate mult la Dumnezeu pentru iertare) $)^{24}$.

Pocăința trebuie făcută aşadar în Biserică (fiindcă Biserica-i spital nu tribunal $)^{25}$, ori de câte ori este nevoie, fără a ne pierde nădejdea în mila şi ajutorul lui Dumnezeu: „Ai păcătuit? Intră în Biserică şi şterge-ți păcatul! Nu-i aşa că de câte ori cazi când mergi pe drum tot de atâtea ori te şi ridici? Fă tot aşa, de câte ori păcătuieşti, pocăieşte-te de păcat, nu deznădăjdui!"26. Însă, pentru că nu dorim să extindem doctrina hrisostomică despre pocăință, ne vom opri în chip deosebit asupra unui aspect al ei: cel al milei ori al binefacerii. Pentru a înțelege valoarea şi importanța acestei virtuți în gândirea şi concepția Sfântului Ioan Gură de Aur, trebuie să arătăm modul în care acest Sfânt Părinte al Bisericii înțelege semnificația Trupului lui Iisus Hristos. În lucrările şi scrierile sale, Sfântul Ioan Hrisostom ne arată şi ne demonstrează că Mântuitorul nostru Iisus Hristos se identifică atât cu Trupul Euharistic, totodată şi cu fiecare membru şi mădular al Bisericii. De aceea, cel ce vrea să se împărtăşească de Trupul şi Sângele Său - Euharistic, trebuie ca mai întâi să-şi îndrepte atenția asupra aproapelui său, oricare şi oricine ar fi acesta.

Domnul nostru Iisus Hristos doreşte să Îl cinstim precum voieşte El, nu precum vor ori cred oamenii că ar trebui cinstit. De

„Adevăr vă zic vouă, întrucât ați făcut unuia dintre aceşti frați ai Mei, prea mici, Mie Mi-ați făcut” (Mat. 25, 40). Milostenia, deci, uşurează toate păcatele tale, oricâte ai avea. (Ex. Pilda celor 10 fecioare, Ilie cu văduva din Sarepta Sidonului) Omilia III, p. $47-52$.

${ }^{22}$ Pr. Gheorghe Tilea, op. cit., p. $636-637$.

23 „Dar mai o cale, tot atât de lesnicioasă, prin care poți scăpa de păcate. Rugăciunea! Roagă-te în fiecare clipă! Nu pregeta a te ruga, nici nu cere cu trândăveală iubirea de oameni a lui Dumnezeu! Dumnezeu nu-ți întoarce spatele de-L rogi cu stăruință, ci-ți iartă păcatele şi-ți împlineşte cererea”. Sfântul Ioan Gură de Aur, Omilii despre pocăință, Omilia III, p. 57.

${ }^{24}$ Pr. Gheorghe Tilea, op. cit., p. 637.

${ }^{25}$ Sfântul Ioan Gură de Aur, Omilii despre pocăință, Omilia III, p. 57.

${ }^{26}$ Ibidem, p. 58. 
aceea, Sfântul Ioan condamnă obiceiul unora de a aduce daruri sfinte la Biserică în detrimentul aproapelui lor, care rămâne în continuare gol, flămând şi însetat. Un astfel de gest, de a împodobi biserica construită, nu îl curățeşte pe creștin, pe când celelalte fapte de milostenie, da. „Biserica nu este un loc unde se adună vase de aur şi de argint, ci un loc de adunare a îngerilor; de aceea trebuie să aducem la biserică sufletele noastre. Dumnezeu se apropie de darurile noastre de aur numai dacă şi sufletul nostru este de aur. Nu era de argint masa aceea de la Cina cea de taina, nici nu era de aur potirul din care a dat Iisus Hristos ucenicilor Sângele Său! Dar toate erau de preț, toate înfricoşătoare, pentru că erau pline de Sfântul Duh! Vrei să cinsteşti trupul lui Hristos? Nu-L trece cu vederea când este dezbrăcat! Nu-L cinsti aici în biserică cu haine de mătase, iar afară îl laşi să degere de frig, că n-are cu ce se îmbrăca! Cel ce a spus: „Acesta este Trupul Meu”, şi prin cuvânt a întărit lucrul, Acelaşi a spus şi „Flămând M-aţi văzut şi nu M-ați hrănit” şi „Întrucât n-ați făcut unuia dintre aceşti prea mici, nici Mie nu Mi-ați făcut". Trupul lui Hristos de pe altar nu are nevoie de acoperăminte prețioase, ci de suflet curat; dar cel gol, cel flămând are nevoie de multă îngrijire. Să învățăm, dar, să filozofăm şi să cinstim pe Hristos, aşa cum vrea El. Cea mai plăcută cinste pentru Cel pe Care Îl cinstim este să-L cinstim aşa cum se cuvine, cum vrea El, nu cum socotim noi. Şi Petru socotea că-L cinsteşte, oprindu-L să-I spele picioarele. Dar ceea ce voia să facă nu era cinste, ci cu totul dimpotrivă. Tot aşa şi tu, cinsteşte-L pe Hristos cu cinstea pe care El ți-a poruncit-o, cheltuind cu săracii avuția ta. Dumnezeu n-are nevoie de vase de aur, ci de suflete de aur" ${ }^{27}$. „Noi trebuie să-L hrănim pe Hristos, să-L

\footnotetext{
${ }^{27}$ Sfântul Ioan Gură de Aur, Omilia L, in Scrieri partea a treia, Omilii la Matei, p. 584: „Nici un Iuda să nu se apropie de această Masă, nici un Simon Magul! Că şi unul şi altul au pierit din pricina iubirii de argint! Să fugim de această prăpastie; nici să socotim că ne este de ajuns pentru mântuire dacă facem dar acestei sfinte mese un potir de aur bătut în pietre scumpe, dezbrăcând pe văduvă şi pe orfani. Dacă vrei să cinsteşti jertfa, adu-i sufletul pentru care Sa jertfit. Sufletul fă-ți-l de aur. Care ți-i câş̧igul dacă sufletul ți-i mai rău decât plumbul şi lutul, iar potirul dăruit, de aur? Nici unul!"
} 
adăpăm şi să-L îmbrăcăm. Acestea sunt vrednice de această masă sfântă" ${ }^{28}$. Acestea sunt motivele pentru care Sfântul Ioan Gură de Aur cere tuturor credincioşilor să se aplece cu stăruință asupra acestei virtuți, fiindcă „Cel ce miluieşte pe sărac, împrumută pe Dumnezeu" (Pilde 19, 17). Multe sunt lucrurile care caracterizează creştinismul, dar, mai mult decât toate şi mai bine decât toate, iubirea reciprocă dintre oameni şi pacea" ${ }^{29}$.

Potrivit Sfântului Apostol şi Evanghelist Ioan (I Ioan 4, 20 21) iubirea este capul virtuților, acest lucru fiind temelia tuturor poruncilor lui Dumnezeu, căci ,prin iubirea față de Dumnezeu intră

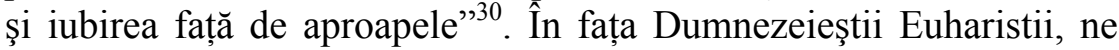
învață Sfântul Ioan Hrisostom, trebuie să se vină cu iubire de Dumnezeu. Trupul şi Sângele Domnului trebuie mâncat şi băut numai de iubitorii Lui, şi iubitori ai Lui nu pot fi cei care urăsc şi trec cu vederea pe aproapele $\operatorname{lor}^{31}$. Cei care doresc să călătorească cu această faptă bună spre Împărăţia lui Dumnezeu, trebuie să fie ferm convinşi de faptul că: „Nu există păcat pe care să nu fie în stare să-1 curețe milostenia, pe care să nu-1 poată ea stinge... ea este un leac prielnic pentru orice rană... Este cu drept cuvânt, desăvârşire" ${ }^{\text {"32; }}$ „Mila este baie a sufletului. De aceea, aşa cum în faţa uşilor bisericii sunt vase de spălat pline cu apă, ca să-ți speli mâinile, la fel, afară din biserică stau jos săracii, ca să-ți speli de pete mâinile sufletului"’33;

${ }^{28}$ Idem, Omilia XXVII, în Comentariile sau explicarea Epiostolei I către Corinteni..., p. 375.

${ }^{29}$ Idem, Omilia XXXI, in Comentariile sau explicarea Epistolei către Evrei, p. 53.

${ }^{30}$ Idem, Omilia LV, 3 in Omilii la Facere, vol. II, traducere din limba greacă veche şi note de Pr. Prof. Dr. Dumitru Fecioru, E.I.B.M.B.O.R., Bucureşti, 2003 , p. $284-285$.

${ }^{31}$ Idem, Omilia XXVII, în Comentariile sau explicarea Epistolei I către Corinteni..., Sfântul Ioan Gură de Aur, Omiliile LXXXII (2) şi L (4), în Scrieri partea a treia, Omilii la Matei

${ }^{32}$ Idem, Omilia XXV, in Comentariu la Faptele Apostolilor, vol. II, lucrare de licență de Ioan Goje, Sibiu, 1986, p. 7.

${ }^{33}$ Pr. Gheorghe Tilea, op. cit. , p. 636 - 637. 
„Oricât de mare ar fi păcatul, mila este în stare să-1 spele”34. Pentru a ne atrage şi mai mult spre a înfăptui acte de milostenie, Sfântul Ioan Gură de Aur ne dovedeşte că Împărăția Cerurilor poate fi „cumpărată” de aici de pe pământ, prin faptele noastre de milostenie față de aproapele nostru, oricine şi oricare ar fi el: „Cerul este neguțătorie şi afacere bună, iar noi o neglijăm. Dă o bucată de pâine şi ia Raiul; dă lucruri mici şi ia lucruri mari; dă cele pieritoare şi ia pe cele nepieritoare; dă pe cele stricăcioase şi ia cele nestricăcioase"35. Totuşi faptele noastre bune trebuie săvârşite din toată inima, pentru că „fapta făcută de silă nu are plată, ci fapta făcută de bunăvoie”,36.

Aşadar, toată viața noastră trebuie să „,fim aplecați spre săvârşirea binelui" ${ }^{37}$. Dacă ne întrebăm care este timpul cel mai potrivit pentru pocăință (sub toate cele cinci aspecte prezentate de Sfântul Ioan), tot el ne dă răspunsul: postul ${ }^{38}$. Postul trebuie să fie îndrăgit şi îmbrățişat de fiecare creştin, deoarece acesta alungă şi învinge duşmanii mântuirii noastre ${ }^{39}$. La fel ca în cazul oricărei alte virtuți ,postul iubeşte pe cei ce îl iubesc şi urăşte pe cei ce îl urăsc" ${ }^{40}$.

În altă ordine de idei, am văzut şi constatat că atât păcatele cât şi virtuțile sunt deopotrivă sufleteşti şi trupeşti. Sfântul Ioan Gură de Aur acordă o importanță deosebită (şi) păcatelor săvârşite prin intermediul trupului. El are în vedere mai cu seamă, acele organe ale trupului care intră în contact nemijlocit cu Trupul şi Sângele

${ }^{34}$ Ibidem, 637.
${ }^{35}$ Sfântul Ioan Gură de Aur, Omilii despre pocăințăa, Omilia III, p. 49.
${ }^{36}$ Ibidem, p. 51.
${ }^{37}$ Mitropolit Srafim Joantă, Deasa sau rara impărtăşire, în Sf. Nicodim Aghioritul, Neofit Kavsokalivitul, Deasa impărtăşire cu Preacuratele lui Hristos Taine, Editura „Reîntregirea”, ediția a II - a, Alba Iulia, 2001, p. 21.

38 „Şi care timp poate fi, oare, mai potrivit pentru pocăință decât timpul postului?" Sfântul Ioan Gură de Aur, Omilia V, în Omilii despre pocăință, p. 84 39 „Când postul alungă aşa pe duȘmanii mântuirii noastre, când este atât de înfricoşător vrăşmaşilor vieții, nu trebuie, oare, să-l iubim şi să-l îmbrăţişăm, şi să nu ne temem de el?... Când postul cu duşmanii noştri, când ne scapă de robie şi ne duce din nou la libertate, ce altă dovadă mai cauți de prietenia postului, de prietenia lui pentru neamul omenesc?"..., idem, Omilia V, p. 79.

${ }^{40}$ Ibidem, p. 80. 
Mântuitorului nostru Iisus Hristos, fără însă a le exclude pe celelalte. Astfel, dintre toate mădularele noastre, limba este organul prin care creştinul greşeşte şi păcătuieşte cel mai mult şi cel mai des, fapt ce ni-1 relatează şi confirmă şi Sfântul Apostol Iacov în Epistola sa şi care spune că „Limba, mic mădular este şi cât codru aprinde...”. „Gura se murdăreşte cu defăimări, blasfemii, ocări, cuvinte pline de mânie, cuvinte de ruşine, râs şi glume" 41 . Împotriva acestor păcate care se săvârşesc prin intermediul limbii, Sfântul Ioan Hrisostom este foarte categoric: „Păziți-vă, dar. Limba mai mult decât lumina ochilor! Limba este cal împărătesc; dacă-i pui frâu şi o înveți să meargă frumos, împăratul se va odihni pe ea şi va sta pe ea; dar dacă o laşi să umble fără frâu şi să zburde, ajunge căruța diavolului şi a demonilor" ${ }^{\prime 2} . \mathrm{Cu}$ toate că nouă ni se pare că păcatele săvârşite prin intermediul ei sunt nesemnificative, Sfântul Ioan este de altă părere şi anume că: ocara şi insulta sunt păcate ce ne aruncă în iad ${ }^{43}$. Trebuie să ştim că nu este suficient a ne spăla gura înainte de a merge la Biserică $^{44}$, ci trebuie, mai înainte de aceasta să ne împodobim limba cu blândețe, smerenie, binecuvântare, cuvintele legilor dumnezeieşti, milostenie ${ }^{45}$.

Acelaşi lucru trebuie să facem şi cu mâinile, ochii şi urechile noastre, şi în general tot trupul nostru trebuie deprins cu virtutea. În ajutor ne vine tot Sfântul Ioan Gură de Aur care ne arată şi modul în care putem săvârşi aceasta: „Cercetează-ți cu luare aminte mâna dreaptă, limba, buzele, care au devenit porțile de intrare ale lui Iisus Hristos. Gândeşte-te la timpul în care te apropii de Sfintele Taine şi

${ }^{41}$ Idem, Omilia L, în Scrieri partea a treia, Omilii la Matei, p. 595 - 596.

${ }^{42}$ Ibidem, p. 596.

${ }^{43}$ Ibidem, p. 596 - 597.

${ }^{44}$ Idem, Omilia V, la Epistola I către Timotei, în Comentariile sau explicarea Epistolelor Pastorale I şi II Timotei, Tit şi Filimon a celui întru sfinți părintelui nostru Ioan Chrisostom, Arhiepiscopul Constantinopolei, traducere din limba greacă, ediția de Oxonia, 1861, de Arhiereul Theodosie Athanasiu Ploeşteanu, Vicariul Sfintei Mitropolii a Ungro-Vlahiei şi Locotenent de Mitropolit Primat, Atelierele grafice SOCE\&CO, Bucureşti, 1911, p. 51 - 52.

${ }^{45}$ Ibidem, p. 52. 
întinzând o masă văzută, îndreaptă-ți cugetul spre acea masă, adică vreau să zic, spre Cina Domnului, spre privegherea ucenicilor din acea noapte sfântă"46; prin urmare ,atunci când vei cugeta ce a pătimit pentru tine Stăpânul, vei fi mai cu băgare de seamă şi mai filozof"47.

În concluzie, Sfântul Ioan Gură de Aur îndeamnă pe tot credinciosul care doreşte să se unească cu Domnul Iisus Hristos în cadrul Sfintei Liturghii, să facă eforturi pentru a dobândi o conştiință curată (eforturi susţinute de Harul lui Dumnezeu). Acest efort implică o parte negativă şi una pozitivă.Cea negativă presupune părăsirea păcatului (indiferent de natura lui, trupesc ori sufletesc), iar partea pozitivă înseamnă colaborarea şi împreună lucrarea noastră cu Domnul şi Mântuitorul nostru Iisus Hristos la cultivarea şi (de)săvârşirea virtuților (care implică şi trupul, după cum am arătat mai sus. Toate virtuțile au drept scop transformarea noastră lăuntrică, astfel încât noi să devenim deopotrivă cu îngerii (blânzi, milostivi, rugători), atunci când ne apropiem de înfricoşătoarele lui Hristos Taine. Ca atare, toate acestea sunt posibile cu condiția ca noi „să nu ne lenevim spre mântuirea noastră ${ }^{\prime 48}$. Starea şi dispoziția de evlavie euharistică, ca de altfel starea de evlavie în general, nu poate rezulta numai dintr-un efort şi solicitare spirituală de moment, ori una mai îndelungată, ci dintr-un permanent exercițiu spiritual, dintr-o continuă deprindere a inimii şi gândului de la cele pământeşti, spre o viață filosofică, adică în Iisus Hristos, cum ne îndeamnă Sfântul Ioan Gură de Aur în încheierea fiecăreia din predicile sale ${ }^{49}$.

Am afirmat şi susținut că noi suntem ajutați în permanență de Harul lui Dumnezeu, însă acest Har ni se comunică nouă cu prisosință atunci când ne împărtăşim. Mai mult, noi nu putem ajunge la unirea cu Dumnezeu (după har) decât prin primirea lui Iisus Hristos Euharistic. Prin aceasta noi dobândim încă de pe acum

\footnotetext{
${ }^{46}$ Idem, Omilia XXVII, în Comentariile sau explicarea Epistolei I către Corinteni..., p. 375.

${ }^{47}$ Ibidem, p. 376.

${ }^{48}$ Idem, Omilia V, la Epistola I către Timotei, în Comentariile sau explicarea Epistolelor Pastorale..., p. 51.

${ }^{49}$ Pr. Gheorghe Tilea, op. cit., p. 636.
} 
siguranța că vom trăi veşnic împreună cu El. Este o legătură tainică între partea omului şi cea a lui Dumnezeu în lucrarea virtuții. Nu se poate ajunge la aceasta fără participarea ambelor părți, însă trebuie să subliniem că ajutorul lui Dumnezeu (dat nouă prin intermediul Sfintei Împărtăşanii) este covârşitor: „virtutea nu se agoniseşte fără lucrarea poruncilor, iar porunca nu se săvârşeşte fără dragoste, şi nici dragostea nu se reînnoieşte fără Sfânta Împărtăşire. Astfel că fără Sfânta Împărtăşire este zadarnic să ne ostenim" ${ }^{, 0}$.

\section{Participarea la Cultul divin public}

\subsection{Venirea la Biserică şi ținuta în cadrul Sfintei Liturghii}

Pentru ca cineva să se poată împărtăşi cu Sfintele Taine, trebuie ca mai întâi de toate să vină la Biserică. Din perspectiva Sfântului Ioan Hrisostom, orice creştin care vine la Sfânta Liturghie este dator să se şi împărtăşească la momentul potrivit şi cuvenit. Sfântul Ioan nu împarte credincioşii în două categorii: cei care doar asistă la slujbă şi cei care se împărtăşesc. Nu! Ci odată ce ai venit la biserică, trebuie să fii pregătit să te şi împărtăş̧eşti. Ca stare sufletească, noi trebuie să păstrăm o linişte totală, fiind atenți la desfăşurarea Sfintei Slujbe, fiind convinşi că ne aflăm în prezența lui Iisus Hristos Însuşi. De asemenea, în timpul Sfintei Liturghii credinciosului i se cere o participare activă şi conştientă ${ }^{51}$. Mai mult decât atât, toți trebuie să fim înflăcăraţi şi entuziasmați, să avem sufletele clocotitoare, să fim cu minţile treze şi să nu ne apropiem cu scârbă sau cu paşi şovăitori ${ }^{52}$. Aceasta nu este un lucru imposibil ori cu neputință de îndeplinit, mai ales dacă ținem seama că „din cele o sută şaizeci şi opt de ceasuri ale săptămânii,

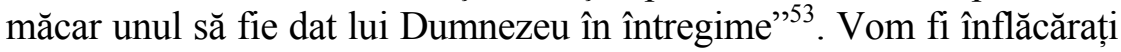
şi entuziasmați, vom avea minţile treze doar dacă, mai dinainte de a

${ }^{50}$ Sf. Nicodim Aghioritul, Neofit Kavsokalivitul, Deasa împărtăşire..., p. 49.

${ }^{51}$ Pr. Gheorghe Tilea, op. cit., p. 645.

${ }^{52}$ Sfântul Ioan Gură de Aur, Omilia LXXXII, în Scrieri partea a treia, Omilii la Matei, p. 934 - 935.

${ }^{53}$ Idem, Omilia IX, în Omilii despre pocăință, p. 178. 
veni la biserică, ne-am cercetat pe noi înşine (potrivit Cuvântului Sfântului Apostol Pavel: „Să se cerceteze omul pe sine şi aşa să mănânce din Pâine şi să bea din Pahar" - I Cor. 11, 28). Drept urmare, cercetarea de sine este obligatorie pentru a nu ne împărtăşi cu nevrednicie, căci, cel ce face aceasta, vinovat este faţă de Trupul şi Sângele Mântuitorului (I Cor. 11, 23 - 31).

Am văzut că Sfântul Ioan Hrisostom consideră păcatul (oricare ar fi el - cu fapta, cu gândul sau cu lucrul) un obstacol şi o piedică în vederea unirii cu Iisus Hristos în Euharistie. De aceea, pentru a scăpa de ele, trebuie mai întâi să le (re)cunoaştem pe fiecare în parte (fiindcă doar conştiința noastră proprie le ştie pe toate), iar cunoscându-le să ne debarasăm şi îndepărtăm de ele. Trebuie să ne înfățişăm înaintea Domnului nostru Iisus Hristos nu doar cu trupul curat, ci mai ales cu sufletul, în alt fel fiind vrednici de toată osânda: „Să cunoaştem, dar, care sunt cele ce spurcă pe om! Să le cunoaştem şi să fugim de ele! Văd că mulți au un astfel de obicei în biserică; se sârguiesc să vină la biserică cu haine curate, cu mâinile spălate; dar ca să se înfățişeze cu sufletul curat înaintea lui Dumnezeu nu suflă nimeni vreun cuvânt! Şi spun lucrul acesta nu ca să vă opresc să vă spălați mâinile sau gura, ci că vreau să vă spălați aşa cum se cuvine, nu numai cu apă, ci, în loc de apă, cu virtuți. Gura se murdăreşte cu defăimări, blasfemii, ocări, cuvinte pline de mânie, cuvinte de ruşine, râs şi glume. Dacă te ştii că nu rosteşti nici una din acestea, nici nu eşti murdărit cu această murdărie, îndrăzneşte de vino la biserică; dar dacă te-ai întinat de nenumărate ori cu aceste pete, pentru ce te osteneşti degeaba clătindu-ți gura cu apă, dar purtând pe ea această murdărie vătămătoare şi ucigătoare" $"$.

\subsection{Problema desei sau rarei împărtăşiri}

În privința acestei probleme, Sfântul Ioan Hrisostom este la fel de neşovăitor, ca şi până acum. El spune că nu trebuie să vorbim de deasa sau rara împărtăşire, ci doar dacă noi avem ori nu o conştiință

${ }^{54}$ Idem, Omilia L, în Scrieri partea a treia, Omilii la Matei..., p. 595. 
curată. Aceasta este cea care ne îndeamnă să ne împărtăşim, ori nu. Cel care are o conştiinţă curată este vrednic şi dator - potrivit convingerilor Sfântului Ioan Gură de Aur - să se împărtăşească ori de câte ori participă la Sfânta şi Dumnezeiasca Liturghie. Dimpotrivă, cel ce nu s-a îngrijit să-şi curățească sufletul, deci cel cu o conştiinţă pătată, murdară şi necurată, nu se poate împărtăşi nici măcar o singură dată pe an, întrucât timpul nu este dictat de vreo sărbătoare (deşi există concepția aceasta în timpul Sfântului Ioan, idee care mai persistă şi astăzi), fie ea chiar Sfintele Paşti.”Apoi, acesta este răul cel mare, că tu hotăreşti vrednicia apropierii de Sfintele Taine nu după curăția cugetului, ci după intervalul de timp, şi crezi că aceasta este evlavie, de a nu te apropia de multe ori în cursul anului de Sfânta Împărtăşanie, neştiind, se vede, că dacă te apropii cu nevrednicie, fie chiar numai odată, aceasta îţi pătează şi înfierează sufletul; iar dacă te-ai apropiat cu vrednicie, fie chiar şi numai odată, ți 1-ai mântuit" ${ }^{\text {"55 }}$. "Ştiu că mulți dintre noi ne apropiem de această Sfântă Masă, pentru că este obiceiul ca la această sărbătoare să ne împărtăşim. Ar trebui, însă, aşa precum v-am spus de multe ori şi mai înainte, să nu ținem seama de sărbătoare când avem să ne împărtăşim, ci să ne curățim cugetul, şi atunci să ne apropiem de Sfânta Jertfă. Cel pângărit şi necurat nici în sărbători nu are dreptul să se împărtăşească cu acest Trup sfânt şi înfricoşător; cel curat însă, cel care şi-a şters bine, prin pocăință, păcatele, acela are dreptul, şi în sărbători, şi oricând, să se împărtăşească cu dumnezeieştile Taine, acela merită să se bucure de darurile lui Dumnezeu. Dar nu ştiu cum se face că unii nu țin seama de lucrul acesta, şi mulţi creştini, plini de mii şi mii de păcate, când văd că vine sărbătoare, ca şi cum ar fi împinşi chiar de sărbătoare, se apropie de Sfintele Taine, pe care nişte oameni ca aceştia nici n-au dreptul să le vadă; pe cei pe care îi cunoaştem îi oprim, iar pe cei pe care nu-i cunoaştem îi lăsăm în seama lui Dumnezeu, Cel ce ştie

${ }^{55}$ Idem, Omilia V, la Epistola I către Timotei, în Comentariile sau explicarea Epistolelor pastorale..., p. 50. 
ascunzişurile inimii fiecăruia" ${ }^{, 56}$.

Aşadar, Sfântul Ioan Gură de Aur condamnă falsa evlavie a unora de a se împărtăşi doar în sărbătorile mari de peste an, cum ar fi: Naşterea Domnului, Botezul Domnului şi Învierea Domnului, ca şi cum această împărtăşire rară i-ar îndreptăți şi justifica ori scuza în fața lui Dumnezeu. „Văd pe mulți împărtăşindu-se cu trupul lui Iisus Hristos, cum s-ar întâmpla, mai mult ca obicei şi ca lege, decât ca impus de cuget. Când va sosi, zice, timpul sfântului mare post, sau când va sosi ziua Arătării Domnului (Teofania sau Epifania) mă voi împărtăşi cu Sfintele Taine, deşi timpul de câştig nu este Epifania, nici Postul Mare, ci sinceritatea şi curățenia sufletului. $\mathrm{Cu}$ acestea apropie-te, fără acestea, însă, niciodată ${ }^{57}$. Nu sunt de lăudat nici cei ce se împărtăşesc de multe ori pe an, chiar de este la fiecare Sfântă Liturghie, dacă fac aceasta având o conştiință pătată, alterată, degradată. Noi trebuie să urmăm exemplul celor care se unesc cu Iisus Hristos, fiind sfătuiți şi îndrumaţi la aceasta doar de conştiinţă, care nu-i judecă pentru faptele lor. „mulți dintre voi se împărtăşesc din jertfa aceasta o singură dată în cursul anului, alții de două ori iar alții de mai multe ori. Deci cuvântul nostru este îndreptat spre toți, nu doar către cei de față, ci şi către cei ce stau prin pustii, căci aceia mai cu seamă o singură dată în an se împărtăşesc, de multe ori şi la doi ani. Deci ce? Pe care, oare, vom aproba noi? Pe cei ce se împărtăşesc o dată, sau pe cei de mai multe roi, ori pe cei de mai puține ori? Nici pe cei de o dată, nici pe cei de mai multe ori, nici pe cei de puține ori, ci pe cei cu cuget curat, pe cei cu inima curată, pe cei cu viață fără de prihană. Unii ca aceştia, apropiindu-se pururea, iară de nu sunt aşa, să nu se apropie niciodată. De ce+ Fiindcă îşi iau cu sine judecata şi osânda şi pedeapsă nespusă. Şi să nu te minunezi de aceasta, căci precum mâncarea, care prin natura sa este hrănitoare, cade într-un stomac bolnav şi bicisnic şi vatămă şi strică totul, devenind cauza bolilor, întocmai aşa se petrece şi cu împărtăşirea Sfintelor şi

\footnotetext{
${ }^{56}$ Idem, Cuvânt la Botezul Domnului, IV, în Predici la Sărbători Împărăteşti şi Cuvântări de laudă la Sfinți, p. 42.

${ }^{57}$ Idem, Omilia III, în Comentariile sau explicarea epistolei către Efeseni..., p. 30 .
} 
dumnezeieştilor Taine" ${ }^{\text {"58 }}$.

Toate acestea ni le spune Sfântul Ioan Hrisostom nu pentru a ne împiedica pe noi să ne apropiem de Sfintele Taine, chiar şi numai în sărbători, ci dimpotrivă, el doreşte să ne apropiem continuu de Ele $^{59}$, dar nu oricum; pentru că cel ce se împărtăşeşte cu nevrednicie, fie şi numai o singură dată în an, este la fel de vinovat ca şi cei care L-au răstignit pe Iisus Hristos: „Îndrăzneala nu este a te apropia de mai multe ori în cursul anului, ci de a te apropia cu nevrednicie, fie chiar şi doar o singură dată în tot timpul anului. Noi, însă, ne găsim într-o asemenea stare de ticăloşie şi îndobitocire, că deşi în cursul anului facem mii de rele, totuşi pentru îndepărtarea de acele rele nu avem nici o grijă, ci credem că ne este de ajuns de a nu îndrăzni ca să ne apropiem des de trupul lui Iisus Hristos, sau ne apropiem cu batjocură, neînțelegând pare-se, că cei ce au răstignit pe Domnul nostru Iisus Hristos, o singură dată l-au răstignit. Dar oare, fiindcă o singură dată 1-au răstignit, păcatul lor este mai mic? Încă şi Iuda, o singură dată 1-a vândut pe Iisus Hristos. Dar ce? Oare faptul acesta 1a scăpat de răspundere? De ce faptul acesta să-1 îndeplinim numai o dată, şi la un anumit timp în cursul anului? Timp de curăție să ne fie nouă curăţia cugetului” ${ }^{60}$. Credinciosul prăznuieşte Sfintele Paşti doar atunci când se împărtăşeşte, iar aceasta o face nu doar o singură dată pe an (atunci când sărbătorim Sfintele Paşti, din punct de vedere istoric), ci de fiecare dată când mâncăm şi bem Trupul şi Sângele Domnului şi Mântuitorului nostru Iisus Hristos. Cei care nu se împărtăşesc, ci doar postesc, se aseamănă catehumenilor, pentru că ei fac acest lucru şi astfel nu simt bucuria Paştilor fiindcă nu se unesc cu Domnul Iisus Hristos: „Sfânta şi marea Patruzecime este o singură dată pe an. Dar paştile le facem (cu alte cuvinte, ne împărtăşim) de

\footnotetext{
${ }^{58}$ Idem, Omilia XVII, în Comentariile sau explicarea Epistolei către Evrei..., p. 231.

59 „Aceasta o spun, nu împiedicându-vă de la apropierea de cele Sfinte o dată în cursul anului, ci pentru că voiesc să vă apropiați permanent de ele", Ibidem, p. $231-232$.

${ }^{60}$ Idem, Omilia V, la Epistola I către Timotei, în Comentariile sau explicarea Epistolelor Pastorale..., p. 50.
} 
trei sau de patru ori pe săptămână; şi ca să zic mai bine, ori de câte ori dorim. Fiindcă nu Postul face Paştile, ci comuniunea şi împărtăşirea care se face la fiecare Liturghie. Şi că lucrul acesta este adevărat, auzi pe Pavel, care zice: „Paştile nostru Hristos S-a jertfit pentru noi" (I Cor. 5, 7). Deci ori de câte ori te împărtăşeşti cu conştiința curată, faci Paştile cele luminate. Nu pentru că ai postit Patruzecimea, ci pentru că te-ai împărtăşit cu Dumnezeieştile Taine" ${ }^{" 61}$. De aceea, cel ce nu este încă botezat, adică catehumenul, niciodată nu face Paştile (chiar dacă posteşte Patruzecimea), deoarece nu se împărtăş̧eşte. Precum şi dimpotrivă, creştinul care nu posteşte, face Paştile când se împărtăşeşte. Precum şi dimpotrivă, creştinul care nu posteşte, face Paştile atunci când se împărtăşeşte, fie azi, fie mâine şi în orice timp se va cumineca. Fiindcă pregătirea cea mai bună şi aleasă pentru împărtăşire nu se judecă după respectarea timpurilor, adică după trecerea celor opt sau patruzeci de zile, şi atunci ne împărtăşim. Nu, ci se judecă după curăţia conştiinței ${ }^{62}$.

Aşadar, cei care nu se apropie de Sfântul Altar spre a se împărtăşi dau dovada faptului că duc o viață duhovnicească nestatornică: când fac păcate, când se îngrijesc să cultivă virtuți (ştiind că trebuie să se împărtăşească), pentru ca mai apoi să revină la cele dintâi. Însă această periodicitate, păcat - virtute nu este decât „, glumă cu Hristos" ${ }^{\prime 3}$. S-a ajuns la periodicitatea trăirii noastre cu Iisus Hristos, la periodicitatea unirii noastre reale cu El, când, de fapt, această unire trebuie să fie permanentă" ${ }^{\prime \prime}$. În vremea Sfântului Ioan Gură de Aur, Sfânta Liturghie se săvârşea de mai multe ori pe săptămână: vineri, sâmbătă, duminică, precum şi în zilele de prăznuire ale mucenicilor ${ }^{65}$. Existau, aşadar (ca şi astăzi), numeroase

${ }^{61}$ Sf. Nicodim Aghioritul, Neofit kavsokalivitul, op. cit., p. 52.

${ }^{62}$ Ibidem, p. 53.

${ }^{63}$ Sfântul Ioan Gură de Aur, Omilia XVII, în Comentariile sau explicarea Epistolei către Evrei..., p. 224.

${ }^{64}$ Pr. Gheorghe Tilea, op. cit., p. 636.

${ }^{65}$ Sfântul Ion Gură de Aur, Omilia V, la Epistola I către Timotei, în Comentariile sau explicarea Epistolelor Pastorale..., p. 50. 
prilejuri şi ocazii de a reînnoi unirea noastră cu Dumnezeu, de a ne întări şi consolida în virtute şi de a părăsi cât mai deplin păcatul.

Referitor la modul cum trebuie să primim Sfintele Taine şi când trebuie să facem aceasta, reținem din cuvintele Sfântului Ioan Hrisostom următoarele: timpul primirii Sfântului Trup şi Sânge al lui Iisus Hristos este conditionat de modul în care trebuie să facem acest lucru, şi anume acela de a ne apropia de aceste Sfinte Taine, având mereu o conştiință curată (cu tot ce include şi implică ea). Aceasta este singura condiție pe care trebuie să o respectăm şi fără împlinirea ei să nu îndrăznim să ne apropiem de Domnul Iisus Hristos Euharistic, niciodată: „,precum v-am spus adesea, s-ar cuveni ca pentru împărtăşit să țineți seama nu de sărbători, ci de curăția conştiinței şi atunci să vă atingeți de Sfânta Jertfă. Căci cel vinovat şi pătat nu se cuvine să se împărtăşească nici în sărbătoare cu acest Sfânt şi Înfricoşător Trup, căci cel care este curat şi spălat de păcatele sale, prin căință desăvârşită, acela este vrednic să se împărtăşească cu dumnezeieştile Taine şi să se bucure de darurile lui Dumnezeu, atât în zi de sărbătoare, cât şi în oricare alt timp"66. Cel ce nu ține cont de aceste lucruri, nu îşi dă seama cu Cine se împărtăşeşte (şi nici măcar pentru ce face aceasta; este doar o obligație, pe care se simte dator, din pricina obişnuinței, să o îndeplinească).

\subsection{Scopul pentru care ne împărtăşim}

Nimic din cele spuse mai sus nu pot avea o rezonanță în viaţa credinciosului dreptmăritor creştin dacă acesta nu ştie care este scopul primirii Sfintelor Taine, mai precis de ce este neapărat nevoie să se împărtăşească cu Iisus Hristos (şi după cum spune Sfântul Ioan Gură de Aur, este ideal ca acest lucru să se întâmple la fiecare Sfântă Liturghie). Îl vom lăsa şi de data aceasta tot pe Sfântul Ioan să ne explice care este acest scop, de ce Iisus Hristos ni se comunică nouă astfel şi de ce trebuie să ne unim cu El ori de câte ori participăm la

\footnotetext{
${ }^{66}$ Idem, Cuvânt la Botezul Domnului, IV, în Predici la Sărbători Împărăteşti..., p. 42 .
} 
Cina Sa. El ne reaminteşte un adevăr recunoscut de toți oamenii, acela că fiecare dintre noi prețuim cel mai mult viața, o viață care însă dorim să fie veşnică. Acest lucru a constituit tema şi subiectul central din propovăduirea Mântuitorului: „Iisus Hristos vorbește adesea despre înviere pentru a imprima în sufletele ascultătorilor acest adevăr. Căci acela era punctul cel mai important din învățătura Sa, să stabilească şi să întărească credința în aceste lucruri: învierea şi viața veşnică. Viața este ceea ce cer oamenii mai mult; nimic nu este mai dulce, nici mai plăcut, ca a nu muri deloc" ${ }^{97}$. Trebuie să ne aducem aminte, continuă Sfântul Ioan, că, în Vechiul Testament, El le promitea o viață lungă însă în Noul Testament ne promite una fără de sfârşit; astfel, comparativ cu mana, care a prelungit viața de pe pământ, Euharistia are scopul şi menirea de a ne ține în viaţă şi dincolo de moarte (ne va înveşnici şi îndumnezei) ${ }^{68}$, întrucât această „mâncare şi băutură duhovnicească” nu este un aliment trimis de Dumnezeu, ci Însuşi Trupul Stăpânului.

Este un lucru bineştiut că viața veşnică nu se poate dobândi de către om doar prin propriile sale puteri, fiindcă omul nu poate face şi mişca nici măcar un singur fir de păr (Matei 5, 36). Atunci, cum putem noi să dobândim acest dar de neprețuit? Răspunsul, pe cât este de simplu, pe atât este de ferm: doar prin participarea noastră la viața Mântuitorului Iisus Hristos, Singurul Care are viață întru Sine. Iar această participare, deoarece vorbim despre o relație între persoane, trebuie să fie una reală, dorită de amândouă părțile. Mântuitorul nostru Iisus Hristos a făcut primul pas, acela de a se întrupa (de a lua firea noastră umană) şi de a o ridica în sferele Sfintei Treimi. Mai mult decât atât, El continuă această operă, de înveşnicire a noastră, prin faptul că acordă, de bunăvoie, fiecăruia dintre cei care doresc, posibilitatea de a-I mânca Trupul şi a-I bea Sângele Său cel Sfânt. Acestea constituie semnul unei iubiri veşnice şi desăvârşite. Ca noi să devenim părtaşi acestei iubiri, în mod real, trebuie să ne unim cu

${ }^{67}$ Sfântul Ioan Gură de Aur, Omilia 46, în Comentariu la Evanghelia de la Ioan, p. 226.

${ }^{68}$ Ibidem, p. 227. 
acest Trup divin. Este efectul pe care îl produce alimentul pe care Mântuitorul Iisus Hristos ni l-a dat pentru a ne face să cunoaştem căldura şi prinosul iubirii Sale. Iată pentru ce a unit El, pentru ce a amestecat Trupul Său cu al nostru, ca noi să fim toți un singur Trup, legat de un singur Cap. Acesta este semnul unei iubiri fierbinți. Iov arăta acest adevăr, atunci când spune despre slujitorii săi că el îi iubea atât de mult, încât ei ar fi dorit să-1 mănânce. Căci, pentru a arăta ataşamentul lor viu şi frumos, ei ziceau: „Unde s-ar fi găsit unul care să nu se fi săturat la masa lui?” (Iov 31, 33). „Iată ce a făcut Iisus Hristos pentru noi; El ne-a oferit carnea Sa să o mâncăm pentru a ne angaja ca să avem pentru El o iubire din cele mai mari şi a ne-o arăta pe aceea pe care o are El pentru noi; El nu s-a făcut numai văzut celor ce doreau să-L contemple, ci S-a lăsat atins, S-a dat să fie mâncat, să fie înfipți dinții în el, absorbind în aşa fel încât să mulțumească cea mai fierbinte iubire" ${ }^{\circ 9}$. „eu am vrut să fiu fratele vostru din iubire faţă de voi, eu am luat trupul şi sângele vostru ca şi unul şi altul să fie comun între voi. Eu vă dau acest trup şi acest sânge, prin care $\mathrm{Eu}$ am devenit de aceeaşi natură cu voi. Tuturor a dat acest trup spre împărtăşire, ca astfel hrănindu-se cu dânsul, şi lepădând de la noi moartea cea dinainte, să ne amestecăm cu dânsul, prin această masă sfântă, şi să intrăm în această viaţă veşnică şi nemuritoare" ${ }^{" 70}$. Noi ne-am născut cu un dor nespus după veşnicie, dar Sfântul Ioan Gură de Aur ne atrage atenția de atâtea ori asupra faptului că acest dor nu îşi poate găsi satisfacerea deplină decât atunci când se alimentează şi se adapă permanent la Izvorul veşniciei, care este unul singur, adică Împărtăşirea cu Însuşi Sfântul Trup şi Sânge al Mântuitorului nostru Iisus Hristos.

Împărtăşania nu este aşadar, o chestiune de alegere, pentru că nu ai posibilitatea să alegi între două lucruri bune, ci trebuie să alegi fie viața (adică a fi mereu cu Iisus Hristos), fie moartea 8prin gestul de a-L refuza constant pe El). El nu se poate rezuma nici la o

${ }^{69}$ Idem, p. 222, precum şi Sfântul Ioan Gură de Aur, Omilia XXIV, în Comentariile sau explicarea Epistolei I către Corinteni..., p. 329.

70 Idem, Omilia XXIV, în Comentariile sau explicarea Epistolei I către Corinteni..., p. 323. 
obişnuinţă, căci dacă ne împărtăşim (fie doar o singură dată) fără a avea o conştiință care să nu ne condamne, nu tragem nici un folos din aceasta $^{71}$, ci dimpotrivă, îl mâniem şi mai mult pe Dumnezeu prin obrăznicia şi impertinenţa noastră. Țelul şi scopul Sfintei Euharistii este însă unul îndoit: nu doar acela de a se uni Iisus Hristos personal cu fiecare dintre cei ce mănâncă şi beau Trupul şi Sângele Său, ci şi ca cei ce se împărtăşesc să se unească între ei. Această unire a lui Dumnezeu cu oamenii şi a acestora întreolaltă este scopul pentru care Iisus Hristos se aduce şi se împarte la fiecare Sfântă şi Dumnezeiască Liturghie. Dar unirea aceasta (sub ambele aspecte) nu se poate săvârşi dacă omul nu îşi dă tot interesul, efortul şi toată osteneala de a face primul pas în această direcție şi privință, mai înainte de a veni la biserică, prin împlinirea poruncilor (cu ajutorul cărora omul se apropie de Dumnezeu, dar şi de aproapele, oricine şi oricare ar fi acesta). Împărtăşirea trebuie doar să consfințească şi să desăvârşească efortul omului de a fi împreună în iubire, atât cu Dumnezeu, cât şi cu oamenii. Această unire între oameni, prin intermediul lui Dumnezeu primit în Sfânta şi Dumnezeiasca Euharistie, formează Biserica ${ }^{72}$ - aceasta a fost şi este înțelesul ei autentic. Odată cu primirea Sfintelor Taine, noi devenim (fiecare în parte) membre, organe şi mădulare ale Corpului lui Iisus Hristos, al Cărui Cap şi este.

${ }^{71}$ „Că astfel de apropiere nu poate fi împărtăşire, cu toate că de nenumărate ori ne vom atinge de acest Sfânt Trup, ci osândă, chin şi adăugire de pedeapsă" Sfântul Ioan Gură de Aur, Puţul, care s-a tălmăcit din limba elinească de Arhiepiscopul şi Mitropolitul a toată Ungrovlahia kir Grigorie Dascălul, pentru folosul neamului nostru, Colecția „Luminătorii Lumii”, Editura „Anastasia”, Bucureşti, 2001, p. 219.

72 „Născută din Trupul şi Sângele Domnului, Biserica nu poate fi vie în afara Trupului şi Sângelui Său. Neputând fi vie în afara dumnezeiştii Euharistii, Biserica lui Iisus Hristos trebuie să se alimenteze continuu din taina ei înşişi, din dumnezeiasca euharistie"; Pr. Gheorghe Tilea, op. cit., p. 648. 


\section{Despre urmările şi efectele primirii Sfintelor Taine}

Ținând seama de cele enunțate mai sus, înseamnă că Sfânta şi Dumnezeiasca Euharistie primită de cei dreptmăritori şi dreptcredincioşi are drept urmare, în primul rând, unirea acestora cu Iisus Hristos, dar şi a lor între ei, laolaltă. „Ce spun eu împărtăşire? Zice, căci noi suntem una cu Trupul acela. Ce este Pâinea din proaducere? Trupul lui Iisus Hristos. Deci ce ajung cei care se împărtăşesc din ea? Trupul lui Iisus Hristos şi numai multe trupuri, ci un singur trup. După cum pâinea, fiind compusă din mai multe boabe de grâu, este unită într-un singur întreg, fără să se vadă ori să se observe undeva boabele de grâu, cu toate că sunt, de fapt, în ființă, în acest fel şi noi ne unim unii cu alții şi cu Iisus Hristos. Tu nu te hrăneşti din alt trup, iar acela din altul, ci din acelaşi ne hrănim cu toții"’33. Acesta este cel mai important şi mai de seamă efect al Sfintei Împărtăşanii, care înseamnă şi împlinirea ori îndeplinirea scopului ei inițial şi prim. Acesta este efectul general pe care Iisus Hristos, prin împărtăşirea cu El, îl produce de fiecare dată când ne unim cu El. Dar trebuie din nou subliniat (chiar dacă poate fi obositor şi obsedant) faptul că acest lucru se produce doar în cazul celor ce se împărtăşesc cu Domnul Iisus Hristos, având o conştiință purificată şi curată.

Venirea lui Iisus Hristos în sufletul şi în trupul nostru are însă şi un efect special sau o consecință deosebită în viața fiecăruia (concret vorbind, în manifestări şi în faptă). De ce? Pentru că unii se apropie cu credință (față de Cel cu Care Se împărtăşeşte) şi bucurie (de a se uni cu Cel pe Care Îl doresc), iar alții cu nepăsare şi cu îndoială. Şi în primul şi în al doilea caz, primirea Trupului şi a Sângelui Domnului nostru Iisus Hristos se alege şi rămâne cu consecințe, atât sufleteşti cât şi trupeşti. Astfel, cei ce 1-au primit pe Iisus Hristos cu inimă deschisă îl simt pe Iisus Hristos, în întreaga lor ființă, care îi copleşeşte cu pace şi cu bucurie. Aceasta îi face să-şi dorească prelungirea acestei trăiri în mod permanent, fiind pe deplin 73 Sfântul Ioan Gură de Aur, Omilia XXIV, în Comentariile sau explicarea
epistolei I către Corinteni..., p. 323 . 
conştienți că, pentru a se realiza acest fapt, se cere şi se impune din partea lor o şi mai mare râvnă în realizarea virtuților ${ }^{74}$. Pentru a înțelege şi mai bine efectele unei Sfinte Împărtăşanii primite cu toată credința, nădejdea şi dragostea, va trebui să-l lăsăm tot pe preaiscusitul nostru Părinte Ioan să ne descrie această stare, ca unul ce a făcut întotdeauna experiența aceasta. „Acest sânge se răspândeşte imediat în suflet imediat ce este băut, el îl adapă şi îl hrăneşte. Acest sânge, când este primit cu vrednicie, îi pune pe fugă pe diavoli, îi face şi-i cheamă să vină la noi pe îngeri şi chiar pe Domnul îngerilor Îl face să vină la noi. Căci imediat ce văd diavolii sângele Domnului, ei fug, dar îngerii vin. Acest sânge, prin spălarea lui a curăţit lumea întreagă ${ }^{, 75}$. „Acest sânge este sfinţirea şi mântuirea sufletului. Acesta îl spală, îl curăţă, îl împodobeşte, îl lărgeşte: el face inteligența noastră mai strălucită decât focul, sufletul mai luminos decât aurul" "76. „Prin acest sânge împodobeşte şi înfrumusețează cu totul Biserica $\mathrm{Sa}^{\text {"77 }}$. „Cei ce iau parte la acest sânge trăiesc împreună cu îngerii, cu arhanghelii şi cu puterile cereşti; ei sunt îmbrăcați cu haina regească a lui Iisus Hristos şi echipaţi cu arme duhovniceşti. Dar este prea puțin spus; ei sunt îmbrăcați chiar cu Regele Însuşi” ${ }^{\prime 7}$. „Sfintele Taine din faţa noastră sunt medicament şi leac vindecător al rănilor noastre, sunt bogăție neîmpuținată, pricinuitoare a Împărăției Cerurilor" ${ }^{, 79}$.

Există, din păcate, şi oameni care fac parte din a doua categorie, adică aceia care se apropie de Sfintele Taine ale lui Iisus

${ }^{74}$ „Să ieşim de la această masă, fraţii mei, ca nişte lei umpluți de căldură şi de foc, grozavi pentru demoni, plini de amintirea capului nostru, şi de această iubire fierbinte despre care El ne-a dat semne aşa de vizibile" - Sfântul Ioan Gură de Aur, Omilia 46, în Comentariu la evanghelia de la Ioan, p. 222.

75 Ibidem, p. 223.

${ }^{76}$ Ibidem, p. 223 - 224.

${ }_{78}^{7 b i d e m, ~ p . ~} 224$.

${ }^{78}$ Ibidem, precum şi Pr. Prof. Dr. Ilie Moldovan, Aspectul hristologic şi pnevmatologic al Bisericii după Sfântul Ioan Gură de Aur, în „Studii Teologice", anul XX (1968), nr. 9 - 10, p. 719.

${ }^{79}$ Idem, Cuvânt la ziua Naşterii Mântuitorului nostru Iisus Hristos, VII, în Predici la Sărbători Împărăteşti..., p. 22. 
Hristos „aşa cum s-ar întâmpla”, fără o pregătire corespunzătoare. Primirea Sfintei Împărtăşanii de către aceştia are urmări şi în viaţa lor. Ele sunt numeroase, Sfântul Ioan Gură de Aur obişnuind să apeleze la cuvintele Sfântului Apostol Pavel, precum descrie toate aceste urmări: „Pentru aceasta sunt mulţi dintre voi neputincioşi, bolnavi şi mulți au murit, că dacă ne-am judeca noi înşine, nu am fi judecați”" (I Cor. 11, 30 - 31). Însă Sfântul Ioan Hrisostom ține să remarce şi să sublinieze un lucru foarte important, şi anume: toate aceste urmări, percepute ca fiind nefaste de către oameni, nu se datorează Sfintelor Taine în sine (deci nu Dumnezeu este cauza lor, căci cum ar putea El să dorească răul oamenilor, din moment ce el ne cheamă la sfințenie), ci ele sunt rodul împărtăşirii unor oameni care nu s-au pregătit pentru aceasta. Ei îşi atrag prin aceasta osânda lui Dumnezeu (care nu doreşte moartea păcătosului, necazurile fiind o pedeapsă în vederea întoarcerii celui ce a greşit ori păcătuit), asemănându-se lui Iuda, datorită faptului că, deşi au fost învredniciți de o atât de mare cinste (aceea de a lua parte la Masa Dumnezeiască şi chiar de a se împărtăşi de rolul ei), n-au cules nici un folos duhovnicesc, rămânând pe mai departe în starea lor de păcătoşenie. „Vai, cât de mare este orbirea vânzătorului! S-a împărtăşit cu Tainele şi a rămas acelaşi; s-a desfătat de masa cea prea înfricoşătoare şi nu s-a schimbat" ${ }^{\prime 0}$. „Păcatul lui Iuda a ajuns mai mare din două pricini. Şi pentru că s-a apropiat de Taine cu asemenea gând, şi pentru că apropiindu-se n-a ajuns mai bun, nici datorită fricii, nici datorită binefacerii primite, nici datorită cinstei ce i s-a făcut ${ }^{81}$; iar toate aceste lucruri se văd în viața lor de zi cu zi: ,plecaţi de la cult, nu se observă la ei nici o îmbunătățire de viață, încât de multe roi era mai bine ca felul acesta de creştini să rămână acasă, spre a unu insulta măcar pe Dumnezeu, căci de felul lor de viață între oameni nu mai pomenim" ${ }^{\prime \prime}$.

\footnotetext{
${ }^{80}$ Idem, Omilia LXXXII, în Scrieri partea a treia, Omilii la Matei, p. 926.

${ }^{81}$ Ibidem, p. 927.

${ }^{82}$ Idem, Omilia XXIX, 3, in Comentariu la Faptele Apostolilor, vol. II, p. 40.
} 


\section{Datoria credinciosului după primirea Sfintelor Taine}

\subsection{De a sta până la sfârşitul Sfintei şi Dumnezeieştii Liturghii}

Aproape toate cuvintele pe care Sfântul Ioan le adresează credincioşilor săi referitor la problema evlaviei euharistice, îi are în vedere pe cei slabi în credință, cei care dau dovadă, prin faptele lor, că nu sunt pe deplin lămuriți asupra importanței pe care o constituie participarea la Sfânta Liturghie şi mai ales împărtăşirea cu Cereştile şi Dumnezeieştile lui Hristos Taine. De o asemenea indiferență şi nepăsare ori aroganță față de Cele Sfinte dau dovadă nu doar cei ce nu se împărtăşesc, sau cei care fac aceasta fără a fi pregătiți, ci şi cei care pleacă de la Sfânta Slujbă, înainte ca aceasta să fi ajuns la sfârşit. Împotriva unora ca acestora Sfântul Ioan Gură de Aur are doar cuvinte de mustrare: „Ce faci tu, omule? În vreme ce Iisus Hristos este de față, în vreme ce îngerii stau de față, în timp ce această înfricoşătoare Masă stă întinsă, în vreme ce frații ți se instruiesc mai departe în Taine, tu, părăsindu-l, pleci? Dar, până şi la o masă oarecare, sigur, de vei fi fost chemat, chiar de te vei fi săturat tu mai întâi, nu cutezi să pleci înaintea prietenilor tăi. Aici însă, în vreme se săvârşesc tainele lui Iisus Hristos, în vreme ce sacrificiul acela este încă pe cale de săvârşire, tu laşi totul la mijloc şi pleci? $\mathrm{Cu}$ ce apărare te vei apăra? Vreți să vă spun a cui faptă împlinesc cei ce pleacă mai înainte de săvârşirea Tainelor, şi de sfârşit, şi nu aduc cântări de mulțumire după sfârşitul Mesei Euharistice? Vi se părea poate spus cu asprime ceea ce am să zic, dar este necesar să zic, din pricina neglijenței celor mai mulți: când Iuda s-a împărtăşit din ultima Cină, în noaptea cea din urmă, când toți ceilalți şedeau mai departe la masă, acela, repezindu-se, a ieşit afară. Pe el îl urmează aceştia care pleacă înainte de ultima rugăciune de mulțumire" ${ }^{n 3}$.

${ }^{83}$ Sfântul Ioan Gură de Aur, Cuvânt la Botezul Domnului, IV, în Predici la sărbători împărăteşti..., p. 43 - 44, precum şi Sfântul Ioan Gură de Aur, Omilia IX, în Omilii despre pocăință, p. 179. 


\subsection{De a mulțumi, cu recunoştință, pentru Sfintele Taine primite}

Pentru ce este atât de important de a sta până la Sfârşitul Sfintei Liturghii, mai ales dacă ne-am împărtăşit? Există o regulă în acest sens, sau este doar râvna unora care au mai multă răbdare decât ceilalți? La toate aceste întrebări şi nelămuriri, Sfântul Ioan ne dă un singur răspuns, însă foarte exact şi precis. Importanța rămânerii la Sfânta Liturghie (deci implicit şi această „,regulă”, care nu trebuie respectată doar de unii, ci de către toți cei ce participă la cultul divin public) până la sfârşit (mai ales după ce ne-am învrednicit să-L primim pe Iisus Hristos), reiese din exemplul dat de Însuşi Mântuitorul nostru Iisus Hristos Apostolilor Săi, după terminarea Cinei celei de Taină. Pornind de la cuvintele Sfintei Scripturi: „Iar după ce au cântat laude, au ieşit la Muntele Măslinilor" (Matei 26, 30), Sfântul Ioan spune că „Trebuie să se ridice de la masă, mulțumind şi cântând lui Dumnezeu laude. Ascultaţi aceste cuvinte toți câți nu aşteptați să se citească cea din urmă rugăciune făcută de Domnul Iisus Hristos după terminarea Cinei cele de Taină. Domnul Hristos a mulțumit înainte de a da ucenicilor Săi Sfintele Taine, ca şi noi să mulțumim; a mulțumit şi a cântat laude şi după ce le-a dat, ca şi noi să facem la fel" ${ }^{14}$.

\section{Concluzii - Liturghia de după Liturghie}

După terminarea Sfintei Liturghii, creştinul este dator să facă dovada faptului că a participat la o masă atât de bogată în daruri duhovniceşti, şi mai ales ca-L poartă în el pe Domnul Iisus Hristos. Iar aceasta o face nu atât prin cuvinte, cât mai ales prin fapte ${ }^{85}$. Ei vor dori întotdeauna să se împărtăşească de Dătătorul păcii şi al bucuriei, dar sunt pe deplin conştienți că pentru aceasta este nevoie de împlinirea pe mai departe a poruncilor Sale. Însă tocmai această

\footnotetext{
${ }^{84}$ Idem, Omilia LXXXII, în Scrieri partea a treia, Omilii la Matei, p. 929.

85 „Să-I mulțumim, să-L slăvim nu numai prin credinţă, ci şi prin fapte” Sfântul Ioan Gură de Aur, Omilia 46, în Comentariu la Evanghelia de la Ioan, p. 224.
} 
unire cu Iisus Hristos îi întăreşte pe unii ca aceştia să îndeplinească cu mai multă uşurință orice este nevoie pentru a nu cădea de la iubirea Lui. Ei se pun în slujba aproapelui, în care Îl văd în permanenţă pe Domnul şi Mântuitorul nostru Iisus Hristos.

$\mathrm{Nu}$ poate exista în viaţa unui creştin adevărat o pauză între o Sfântă Liturghie şi alta, ci acest timp trebuie puternic cultivat şi fructificat, în vederea săvârşirii binelui (şi) în lupta noastră cu păcatele şi cu patimile (deoarece, prin Sfânta Euharistie, nouă ni se iartă păcatele, dar pornirile spre păcat nu pot fi şterse, fiindcă depinde de noi cum ne folosim de puterile şi resursele sufleteşti: rațiune, dorinţă, voință, vigoare, dinamism). Iar acest lucru devine uşor pentru cel ce se gândeşte cu Cine s-a unit, şi că va trebui să-l întâmpine în curând, la fel de curat şi cinstit: ,Să ne gândim atunci în noi înşine la binefacerile cu care ne-a cinstit Mântuitorul Iisus Hristos, ca să ne amintim cât este de minunat duhul pe care l-am primit. Acest gând va îndepărta, înlătura şi va potoli patimile noastre" ${ }^{\text {" }}$.

Dimpotrivă, cei care după primirea unor atât de multe şi mari daruri duhovniceşti se întorc la aceleaşi fapte ruşinoase, sunt la fel de vinovați ca cei ce s-au împărtăşit cu nevrednicie, întrucât şi ei (ca şi ceilalți) îşi atrag mânia lui Dumnezeu, ostenindu-se în zadar: „Te bucuri de masa cea duhovnicească, de masa cea împărătească, şi tu îți umpli gura cu lut? Eşti uns cu mir şi te mânjeşti cu putoare? Căci, spune-mi te rog, după un an de zile, primind Sfânta Împărtăşanie, crezi tu că cele paptruzeci de zile îţi sunt de ajuns spre curăţirea păcatelor din trecut? Şi după trecerea unei săptămâni, te dedai iarăşi celor dintâi? Spune-mi te rog: dacă după trecerea a patruzeci de zile de la însănătoşirea ta de o boală lungă, te dedai iarăşi acelor mâncări aducătoare de boli, oare nu ai pierdut şi munca ta dinainte?... patruzeci de zile întrebuințezi pentru sănătatea sufletului, şi poate că nici patruzeci, şi aştepți ca să îmblânzeşti pe Dumnezeu? Te joci, o omule?"87

\footnotetext{
${ }^{86}$ Ibidem, p. 225.

${ }^{87}$ Idem, Omilia XVII, în Comentariile sau explicarea Epistolei către Evrei..., p. 231.
} 
Pentru a fi şi mai convingător, Sfântul Ioan Hrisostom recurge din nou la exemplul celui ce a fost Apostolul Iuda, arătându-se cruda realitate (dar întru totul adevărată) că precum acestuia nu i-a fost de nici un folos faptul de a fi fost mereu în preajma lui Iisus Hristos, întrucât nu a părăsit păcatul (şi prin aceasta a dobândit nu Împărăția Cerurilor împreună cu Învăţătorul Său, ci Iadul, pentru că deşi era totdeauna cu Domnul Iisus Hristos, inima sa era închinată diavolului), aceeaşi soartă o vor avea toți cei ce se împărtăşesc ce nevrednicie, cât şi cei ce se împărtăşindu-se cu vrednicie, îi întorc spatele lui Dumnezeu, complăcându-se în propriile plăceri: „Că aceste adevăruri ne fac foarte atenţi şi totdeauna veghetori. Dacă cel ce era ales în ceata Apostolilor, care a primit un aşa de mare dar, care a făcut minuni; căci el a fost trimis cu ceilalți pentru a învia morții şi a-i vindeca pe leproşi; dacă, zic eu, un ucenic, pentru că s-a lăsat biruit de cruda şi trista boală a lăcomiei, L-a vândut pe Stăpânul său, dacă atâtea binefaceri şi daruri, dacă nici petrecerea, nici familiaritatea cu Iisus Hristos, nici spălarea picioarelor, nici însoțirea de la masă, nici păstrarea pungii, nu i-au folosit la nimic, sau dacă aceste lucruri lui i-au deschis mai repede prăpastia în care s-a aruncat, să tremurăm şi să ne temem noi înşine, să nu imităm într-o zi pe acest urât şi perfid lacom. Voi nu-L trădaţi pe Iisus Hristos? Dar atunci când îL disprețuieşti pe sărac care se usucă de foame, sau care îngheață de frig ori moare de sete, voi meritaţi soarta şi pedeapsa lui. Şi atunci când luăm parte cu nevrednicie la Sfintele taine, cădem în acelaşi adânc în care s-au aruncat cei ce L-au omorât pe Domnul Iisus Hristos" $" 88$.

Enunțând, în cele din urmă, câteva concluzii, vom afirma şi sublinia că viața în Iisus Hristos o dobândim prin Sfintele Taine, care îşi au baza în Taina originară sau Taina Tainelor care este Domnul şi Mântuitorul nostru Iisus Hristos; dar recunoaştem cu toții, că cea mai plină de mister dintre toate Tainele este Dumnezeu - Omul, Iisus Hristos şi după El este Euharistia şi Biserica. Prin Botez, Mirungere

${ }^{88}$ Sfântul Ioan Gură de Aur, Omilia 46, în Comentariu la Evanghelia de la Ioan, p. 231. 
şi Euharistie ne încorporează în Sine în Trupul Său tainic - Biserica, ne ridică la comuniunea cu Sine aşezându-ne în intimitatea $\mathrm{Sa}$, dăruindu-ne infinita şi nemărginita Sa bogăţie duhovnicească prin care putem să creştem neîncetat „până la măsura bărbatului desăvârşit, a vârstei deplinătăţii lui Iisus Hristos" (Efeseni 4, 13).

În fiecare Taină, Iisus Hristos ni se dăruieşte cu o lucrare a Sa, în Euharistie, însă, ni se dăruieşte cu Însuşi Trupul şi Sângele Său, deplin penetrate de Duhul Lui şi prin care ne spiritualizează şi pe noi, având acordul voinței noastre libere. Euharistia este Taina care - L extinde pe Iisus Hristos în noi, sau prin care suntem noi asimilaţi la umanitatea Sa preamărită prin Înviere şi Înălţare. Această extindere a lui Iisus Hristos în noi constituie Biserica - o comunitate de persoane unite între ele prin acelaşi Trup şi Sânge al lui Iisus Hristos, pline de Duhul Sfânt. Biserica care este astfel constituită ca o comunitate concretă, vizibilă, a oamenilor cu Dumnezeu prin Iisus Hristos în Duhul Sfânt, are la rândul ei puterea sacramentală de a-L extinde mai departe pe Iisus Hristos în alți oameni, prin organele alese şi sfințite de Iisus Hristos Însuşi în ea şi pentru ea, prin Duhul Lui cel Sfânt, adăugând Trupului Său noi mădulare. De asemenea, puterea sacramentală, sfințită şi sfințitoare a Bisericii izvorăşte tot prin puterea lui Iisus Hristos Cel sălăşluit în ea prin Duhul Sfânt. Euharistia şi Biserica sunt două realități nedespărțite, într-o continuă şi indisolubilă legătură, una implicând-o pe cealaltă, una fiind condiție a celeilalte, iar în amândouă este prezent Acelaşi Iisus Hristos prin Trupul Lui, deplin pnevmatizat, atrăgând toate mădularele şi membrele Sale spre înălțimea la care se află El.

\section{6. Încheiere}

Aşadar, importanţa şi semnificaţia Euharistiei sunt fundamentale şi maxime pentru viaţa omului, pentru viaţa lumii, căci ea este unirea cea mai înaltă care se poate realiza între om şi Domnul nostru Iisus Hristos, cu Dumnezeu, în Împărăţia Sa. Dumnezeiasca Împărtăşanie din cadrul Sfintei Liturghii care se săvârşeşte în Biserică pentru credincioşi, ne uneşte cu Iisus Hristos şi pe noi unii 
cu alții, deoarece toți credem în Unicul Iisus Hristos - Care este ieri, azi şi în veci Acelaşi şi prin Care ne împărtăşim cu aceleaşi Sfinte Taine. Ea este Taină a Bisericii şi a unității Bisericii fiindcă în ea se pecetluieşte unitatea de credinţă încununând Liturghia Cuvântului. Ea susţine creşterea permanentă a creştinilor în Iisus Hristos, în Trupul Său tainic - Biserica - în comuniunea iubirii cu Iisus Hristos şi între ei, Euharistia fiind prin aceasta un sacrament al împăcării ${ }^{89}$, al iubirii şi a unităţii profunde a oamenilor în Hristos, a mântuirii în El şi prin El, aşa după cum am mai spus în acest studiu. Unitatea creştină trebuie să se răsfrângă asupra lumii întregi, pentru ca să se pregătească în acest chip unitatea eshatologică pe care Sfânta Împărtăşanie o prefigurează, Împărăţia lui Dumnezeu cea veşnică pe care o pregustăm încă din viața această terestră şi care nu este o comuniune umană, ci o unitate în Dumnezeu, în plenitudinea adevărului şi în bucuria Împărăției ${ }^{90}$ - această concepție ar trebui să asigure ecumenicitatea sau gândirea şi mişcarea ecumenică Bisericii cea una după cum şi Iisus Hristos - Adevăratul Dumnezeu - doar Unul este!....

Încheiem cu constatarea că Euharistia actualizează într-un dinamism convergent, spre plenitudinea existenței, marile potențialități umane care semnifică şi simbolizează ceea ce trebuie să devină lumea adică o dăruire şi un imn de laudă adus, neîncetat, Creatorului; o comuniune universală în Trupul lui Hristos, o împărăție a dreptăţii, a iubirii şi a păcii în Duhul Sfânt, pentru unitatea şi mântuirea tuturor în Hristos Domnul şi prin Hristos, ajungând, astfel, la desăvârşirea noastră cu ajutorul Sfintei Euharistii căreia îi descoperim, în acest fel, valoarea ei duhovnicească de neprețuit.

\footnotetext{
${ }^{89}$ Pr. Dr. Gheorghe Petraru, Euharistia - Taina Unităţii Bisericii şi a mântuirii in Hristos, în revista "Mitropolia Moldovei şi Sucevei", Anul LIX, Nr.10-12, Octombrie-Decembrie (1983), p. 642.

90 Pr. Prof. Dr. Dumitru Stăniloae, Legătura între Euharistie şi iubirea creştină..., p. 33 .
} 


\section{Bibliografie:}

1. Coman, Ioan G., Sensul Ecumenic al Sfintei Euharistii la Sfântul Ioan Gură de Aur, în „Ortodoxia”, anul XVII, 1965.

2. Joantă, Srafim, Deasa sau rara impărtăşire, în Sf. Nicodim Aghioritul, Neofit Kavsokalivitul, Deasa împărtăşire cu Preacuratele lui Hristos Taine, Editura „Reîntregirea”, ediția a II - a, Alba Iulia, 2001.

3. Sfântul Ioan Gură de Aur, Comentarii la Evanghelia de la Ioan, traducere din limba franceză de Diac. Gheorghe Băbuț, Editura „Pelerinul Român”, Oradea, 1997.

4. Idem, Comentariile sau explicarea Epistolei către Evrei a celui întru sfinți părintelui nostru Ioan Chrisostom, Arhiepiscopul Constantinopolei, traducere din limba greacă, ediţia de Oxonia, 1862, de Theodosie Romanul, Episcopul Romanului, Tipografia Cărților Bisericeşti, Bucureşti, 1923.

5. Idem, Comentariile sau explicarea Epistolei I către Corintenii a celui întru sfinți părintelui nostru Ioan Chrisostom, Arhiepiscopul Constantinopolei, traducere din limba greacă, ediția de Oxonia, 1847, de Arhim. Theodosie Atanasiu - Egumenul Mănăstirii Precista Mare din Roman, Atelierele grafice Soce \& Co, Bucureşti, 1908.

6. Idem, Comentariile sau explicarea Epistolelor Pastorale I şi II Timotei, Tit şi Filimon a celui întru sfinți părintelui nostru Ioan Chrisostom, Arhiepiscopul Constantinopolei, traducere din limba greacă, ediția de Oxonia, 1861, de Arhiereul Theodosie Athanasiu Ploeşteanu, Vicariul Sfintei Mitropolii a UngroVlahiei şi Locotenent de Mitropolit Primat, Atelierele grafice SOCE\&CO, Bucureşti, 1911.

7. Idem, Comentariu la Faptele Apostolilor, vol. II, lucrare de licență de Ioan Goje, Sibiu, 1986.

8. Idem, Omilii despre pocăință, traducere, introducere şi note de Pr. Dr. Dumitru Fecioru, E.I.B.M.B.O.R., Bucureşti, 1998.

9. Idem, Omilii în Comentariile sau explicarea Epistolei către Efeseni a celui intru sfinți părintelui nostru Ioan Chrisostom, Arhiepiscopul Constantinopolei, traducere din limba greacă, ediția de Oxonia, 1852.

10. Idem, Omilii la Facere, vol. I și vol. II, traducere din limba greacă veche şi note de Pr. Prof. Dr. Dumitru Fecioru, E.I.B.M.B.O.R., Bucureşti, 2003.

11. Idem, Predici la Sărbători Împărăteşti şi Cuvântări de laudă la sfinți, E.I.B.M.B.O.R., Bucureşti, 2002. 
12. Idem, Puţul, care s-a tălmăcit din limba elinească de Arhiepiscopul şi Mitropolitul a toată Ungrovlahia kir Grigorie Dascălul, pentru folosul neamului nostru, Colecția „Luminătorii Lumii”, Editura „Anastasia”, Bucureşti, 2001 13. Idem, Scrieri partea atreia, Omilii la Matei, traducere, introducere şi note de Pr. Dr. Dumitru Fecioru, Colecția Părinţi şi Scriitori Bisericeşti (PSB), vol 23, E.I.B.M.B.O.R., Bucureşti, 1994.

14. Stăniloae, Dumitru, Taina Euharistiei - izvor de viață spirituală în Ortodoxie, în „Ortodoxia”, anul XXXI, 1979.

15. Telea, Marius, Sfânta Euharistie în gândirea Sfântului Ioan Gură de Aur, în „Revista Teologică”, nr. 1, anul IV, 1994.

16. Tilea, Gheorghe, Evlavia Euharistică după Sfântul Ioan Gură de Aur, în „Studii Teologice”, nr. 9 - 10/1957. 